\title{
Research on Selected Positive Externalities in Road Transport
}

\author{
Vladimír Konečný $^{1 *}$, František Petro ${ }^{1}$, Róbert Berežný ${ }^{1}$ and Miriama Mikušková ${ }^{1}$ \\ ${ }^{1}$ University of Žilina, Department of Road and Urban Transport, Univerzitná 1, 01026 Žilina, \\ Slovak Republic; Email: Vladimir.Konecny@fpedas.uniza.sk, Frantisek.Petro@fpedas.uniza.sk, \\ Robert.Berezny@fpedas.uniza.sk,mikuskova@stud.uniza.sk
}

\section{*Corresponding Author: Vladimír Konečný}

\begin{abstract}
Scientific article deals with the characteristics of positive externalities and identifying positive externalities of road transport. In the analysis are the processed data on economic indicators of the Slovak Republic and data for individual regions of the Slovak Republic. Based on the analysis were selected positive externalities of road transport. At present, there is insufficient attention to the positive externalities of the transportation, and despite the fact that road transport and road infrastructure has undeniable positive impact on social development and economic growth of the country.
\end{abstract}

Keywords: positive externalities, road transport, GDP, transport infrastructure, employment

\section{Introduction}

Transport has a positive impact on the economic and social development of the country. It is one of the basic sectors of the national economy and also affects other economic sectors. Transport is an integral part of the everyday life of the population and, at the same time, conditional on the achievement of the economic growth of the country, increase the competitiveness and prosperity of society. Transport infrastructure and services provided in transport contribute to increasing employment and are an important factor in the inflow of foreign direct investment, supporting tourism development and helping to reduce regional disparities. In Slovakia, road transport is the most used type of transport. Transport is an important source of externalities. In addition to often mentioned negative externalities, road transport also causes undeniable positive externalities. Therefore, it is also important to address the issue of the positive impacts of road transport on society.

\subsection{Positive Externalities}

Positive externalities are the benefits that a third party profits from it as a result of an economic transaction. A third party can be understood as any individual, organization, company, property 
owner, and others who are indirectly affected. Positive externalities should be unlike negative backed up. Demand for goods and services that generate positive externalities can be supported by lowering prices for these goods and services. Also by providing free information to consumers about goods and services, which may mean better understanding of the product and service and increase demand for this product or service. Positive externalities arise in various sectors, in the field of transport may be the construction and operation of infrastructure projects, such as the construction of motorways [1].

\section{Identification of the Positive Externalities from Road Transport}

The following analyzes serve to identify the areas with which are the externalities of transport connected, or identifying the indicators that could be used to quantify the impacts and benefits of road transport.

\subsection{Analysis of Freight Transport Performance}

Road freight transport has the largest market share as a result of liberalization, increasing the number of bulk shipments, greater flexibility, "door-to-door" and also lower costs of using the infrastructure compared to rail transport. Within the regions in the Slovak Republic, the road freight transport also has the largest share. With the increasing demand for foreign goods and the increasing international trade, international road operations are rising.

The average year-on-year growth rate of total freight transport performance in the Slovak Republic in the period 2000 - 2014 is 1.0301 , which means that the transport performance grew by $3 \%$ year-on-year. The transport performance in this period grew year-on-year only in road freight transport by $5.7 \%$.

Based on an analysis of the current performance of road freight transport performance in the Slovak Republic and on the basis of the European Commission's analysis of the expected development of freight transport performance, we can claim that road freight transport performance will continue to grow. The following Table 1 shows the expected development of transport performance in road freight transport in the Slovak Republic. The European Commission has prepared a forecast for the development of European Energy and Transport, Trends to 2030.

Table 1 Forecast of transport performance in freight transport in SVK in bill. tkm. Source: [2]

\begin{tabular}{cccc}
\hline Year & $\mathbf{2 0 2 0}$ & $\mathbf{2 0 2 5}$ & $\mathbf{2 0 3 0}$ \\
\hline $\begin{array}{c}\text { Road freight } \\
\text { transport performance }\end{array}$ & 38.6 & 40.4 & 42.0 \\
\hline
\end{tabular}




\subsection{Analysis of Gross Domestic Product}

The transport sector has a long-standing share of around 6-8\% of GDP in the Slovak Republic. The impact of transport on the economy is directly reflected in the various sectors of the transport industry, making of vehicles, construction of transport infrastructure and indirectly in all sectors of the industry producing raw materials, fuels, semi-finished products, components and equipment for transport [3].

The average GDP growth rate reached 1.0643 between 2000 and 2014, which means GDP grew by $6.4 \%$ year on year. The most significant impact to the creation of the GDP of the Slovak Republic in the monitored period 2000 - 2014 was given by the Bratislava Region. The average share of this region in GDP creation for this period was $26.5 \%$. The region of Košice is $12.1 \%$, Banská Bystrica Region (9.4\%) and Prešov Region (8.7\%) were the least affected by the gross domestic product.

\subsection{Transport Infrastructure Analysis}

The existence of a country's high quality road infrastructure linked to an international network and market access to customers has a significant impact on the location of foreign investment [4].

Besides the negative impact on the environment (especially noise and emissions), the operation of the motorway also has positive effects compared to traffic on other roads, for example the number of traffic accidents is reduced, and the resolution of conflicts of interest in the territory. The construction of motorways also has a positive impact on employment by making it available to investors as well as in economically backward regions, which can reduce the need to transfer labor to greater distances and increase the possibility of employment in home as well as shorter transport times [5].

\subsection{Analysis of Foreign Direct Investment in Regions of Slovakia}

At present, foreign investments represent one of the most effective forms of increasing the competitiveness of the territory. Foreign capital infiltration into the country's economy is taking place and through the moves and introduction of new technologies, the production potential of the region is increasing and, in particular, employment and income growth. The key criterion for the selection of the region from the perspective of investors is the availability of human resources, the local economy and, last but not least, the condition and equipment of the area through the transport infrastructure. Regions in the west (Bratislava Region, Trnava Region) are more developed than the regions of the Central (Banská Bystrica Region) and Eastern Slovakia (Prešov Region, Košice Region) [6]. 


\subsection{Employment Analysis}

The employment rate is expressed as a percentage and represents the share of the working population in the population aged 15-64. The highest employment in the monitored period in 2015 was in the Bratislava Region (71.5\%) and the lowest employment in Košice (58.2\%) and Prešov Region (57.1\%) [7].

\section{Evaluation of Relations Between Road Transport and Indicators of Economic Growth}

Based on previous analyzes of individual economic indicators and available statistical data, a procedure was developed for the purpose of elaborating a methodology for assessing positive externalities from road transport, which is described in more detail in this chapter.

\subsection{Correlation Coefficient}

The correlation coefficient was used to identify relationships between possible indicators in assessing positive externalities from road transport.

If we examine the values of two or more numeric characters, we can assume that there is interdependence between the values of these characters. The correlation coefficient $r_{x y}$ measures the statistical linear dependence between the values of the variables $\mathrm{X}$ and $\mathrm{Y}$. It can be calculated according to:

$$
r_{x y}=\frac{\sum_{i=1}^{n}\left(x_{i}-\bar{x}\right)\left(y_{i}-\bar{y}\right)}{\sqrt{\sum_{i=1}^{n}\left(x_{i}-\bar{x}\right)^{2} \sum_{i=1}^{n}\left(y_{i}-\bar{y}\right)^{2}}},[-]
$$

where: $r_{x y}$ is correlation coefficient, $x$ is variable value, $y$ is variable value, $n$ is number of ordered pairs $\left[\mathrm{x}_{\mathrm{i}}, \mathrm{y}_{\mathrm{i}}\right]$

The correlation coefficient reaches values from the interval $<-1,+1>$. When it comes to independence between $\mathrm{X}$ and $\mathrm{Y}$, the correlation coefficient is 0 . The positive values of the correlation coefficient refer to direct dependence and the negative value refers to indirect dependence [8].

\subsubsection{Evaluation of Relations Between Road Transport Indicators and Indicators of Economic Growth in the Slovak Republic}

To determine the dependence between road transport performance and the development of indicators of the country's economic, the following indicators were selected:

- gross domestic product,

- length of road infrastructure,

- foreign direct investment,

- employment rate. 
In the following Table 2, the correlation matrix is given, where the calculated correlation coefficients are shown. The correlation coefficient between road freight transport performance and GDP is 0.9912. Based on this value, it can be argued that there is a strong direct dependence between road freight transport performance and GDP. This means that the increase in the transport performance will also increase GDP and vice versa. There is also a strong direct dependence between road freight transport performance and other selected indicators of economic growth in the country. We can claim that road freight transport has a positive impact on the growth of economic indicators in the country.

Table 2 Correlation matrix between road freight transport performance and economic indicators in Slovakia. Source: [authors]

\begin{tabular}{cccccc}
\hline Indicator & $\begin{array}{c}\text { Road freight } \\
\text { transport } \\
\text { performance }\end{array}$ & GDP & $\begin{array}{c}\text { Employment } \\
\text { rate }\end{array}$ & $\begin{array}{c}\text { Road } \\
\text { infrastructure }\end{array}$ & $\begin{array}{c}\text { Foreign direct } \\
\text { investment }\end{array}$ \\
\hline $\begin{array}{c}\text { Road freight } \\
\text { transport } \\
\text { performance }\end{array}$ & $\mathrm{x}$ & 0.9912 & 0.8870 & 0.9272 & 0.9634 \\
\hline GDP & 0.9912 & $\mathrm{x}$ & 0.8693 & 0.9397 & 0.9567 \\
\hline $\begin{array}{c}\text { Employment } \\
\text { rate }\end{array}$ & 0.8870 & 0.8693 & $\mathrm{x}$ & 0.7289 & 0.8416 \\
\hline $\begin{array}{c}\text { Road } \\
\text { infrastructure }\end{array}$ & 0.9272 & 0.9397 & 0.7289 & $\mathrm{x}$ & 0.8902 \\
\hline $\begin{array}{c}\text { Foreign direct } \\
\text { investment }\end{array}$ & 0.9634 & 0.9567 & 0.7416 & 0.8902 & $\mathrm{x}$ \\
\hline
\end{tabular}

\subsubsection{Evaluation of Relations Between Road Transport Indicators and Indicators of Economic Growth at Regional Level in the Slovak Republic}

For the analysis of relations between road freight transport performance and economic growth indicators at the regional level through the correlation coefficient were chosen available data on road freight transport performance in individual regions and the following indicators for each region:

- regional gross domestic product,

- number of persons employed in individual regions,

- foreign direct investment by region.

We have examined the relationship between road freight transport performance and GDP through the correlation coefficient and the calculated values refer to the direct dependence between the two indicators. In all regions, there is a strong direct dependence, with the exception of the Košice region. In addition, Table 3 shows the coefficients of the correlation between the number of persons employed and the transport performance of road freight transport in the Slovak Republic. 
The correlation coefficient was calculated from the development of indicators for 2002 to 2014 due to the availability of data. The values of the correlation coefficient express the direct dependence between the two investigated variables except the Trenčín region where the correlation coefficient represents a negative value, which means the indirect weaker dependence between the studied quantities.

Table 3 The values of the correlation coefficient between the road freight transport performance and the indicators selected at regional level. Source: [authors]

\begin{tabular}{lcccccccc}
\hline & \multicolumn{7}{c}{ Regions of Slovak republic } \\
\cline { 2 - 8 } & BA & TT & TN & NR & ZA & BB & PO & KE \\
\cline { 2 - 8 } & \multicolumn{7}{c}{ Road freight transport performance and regional GDP } \\
\hline $\begin{array}{c}\text { Correlation } \\
\text { coefficient }\end{array}$ & 0.8719 & 0.8846 & 0.8357 & 0.8868 & 0.6507 & 0.7319 & 0.9414 & 0.3996 \\
\hline \multicolumn{7}{c}{ Road freight transport performance and number of employees } \\
\hline $\begin{array}{c}\text { Correlation } \\
\text { coefficient }\end{array}$ & 0.3062 & 0.5356 & -0.155 & 0.8494 & 0.4026 & 0.6058 & 0.783 & 0.0767 \\
\hline \multicolumn{7}{c}{ Road freight transport performance and foreign direct investment } \\
\hline $\begin{array}{c}\text { Correlation } \\
\text { coefficient }\end{array}$ & 0.8018 & 0.2471 & 0.7928 & 0.7848 & 0.6288 & 0.482 & 0.8561 & 0.2041 \\
\hline
\end{tabular}
Notes: BA - Bratislava region, $T T$ - Trnava region, $T N-$ Trenčín region, $N R-N i t r a$ region, $Z A-$ Žilina region, $B B$ - Banská Bystrica region, $P O$ - Prešov region, $K E$ - Košice region

\subsection{Index - Quadrant Method}

In order to evaluate the positive externalities from road freight transport and their relationship to transport performance at the regional level, an index quadrant method was used. For the use of the index-quadrant method it was necessary to calculate the year-on-year growth rate of the selected indicator and the year-on-year growth rate of the selected positive externalities from road transport, which were further analyzed in the second chapter of this article. The year-on-year growth rate is determined by means of chain indexes:

$$
i_{p r}=\frac{u_{1}}{u_{0}} ; \frac{u_{2}}{u_{1}} ; \ldots ; \frac{u_{n}}{u_{n-1}}(-)
$$

Indexes that acquire values above 1 represent year-on-year growth, index values below 1 represent a year-on-year decline [9].

\subsubsection{Application of Index - Quadrant Method}

The following tables 4, 5 show the year-on-year growth rate of road freight transport performance and gross domestic product. Given the availability of data, the year-on-year growth rate of road freight transport performance in the Slovak Republic and in individual regions is calculated using 
chain indexes for the years 2003-2014. The year-on-year change of gross domestic product and regional GDP is calculated for 2001-2013 [9].

Table 4 Year-on-year change in road freight transport performance. Source: [authors]

\begin{tabular}{cccccccccc}
\hline \multirow{2}{*}{ Year } & $\begin{array}{c}\text { Slovak } \\
\text { republic }\end{array}$ & \multicolumn{8}{c}{ Regions of Slovak republic } \\
\cline { 2 - 10 } & BA & TT & TN & NR & ZA & BB & PO & KE \\
\hline 2002 & - & - & - & - & - & - & - & - & - \\
\hline 2003 & 1.1293 & 0.8994 & 2.0528 & 1.0330 & 1.1036 & 0.8038 & 0.8397 & 1.0456 & 0.6088 \\
\hline 2004 & 1.0983 & 0.9782 & 0.9631 & 1.3809 & 1.2010 & 1.0469 & 0.9978 & 1.1297 & 0.9828 \\
\hline 2005 & 1.2178 & 1.6053 & 1.2726 & 0.8721 & 1.2335 & 1.1043 & 0.9569 & 1.0088 & 1.4592 \\
\hline 2006 & 0.9807 & 1.6777 & 1.0529 & 1.1519 & 1.0479 & 1.1239 & 1.3607 & 1.1969 & 1.1829 \\
\hline 2007 & 1.2232 & 0.8887 & 1.1169 & 1.6273 & 1.1775 & 1.2177 & 0.9915 & 1.1289 & 0.9305 \\
\hline 2008 & 1.0756 & 1.5076 & 1.2209 & 1.0820 & 1.1777 & 0.9829 & 1.2434 & 1.5425 & 0.8781 \\
\hline 2009 & 0.9447 & 1.0329 & 0.8768 & 1.0758 & 0.7993 & 0.8234 & 1.1509 & 1.1087 & 1.0603 \\
\hline 2010 & 0.9973 & 1.2796 & 1.3411 & 1.3984 & 0.7538 & 1.0082 & 0.8275 & 1.0890 & 0.9478 \\
\hline 2011 & 1.0596 & 1.0278 & 1.1857 & 1.3191 & 1.6790 & 1.5645 & 0.7048 & 1.0061 & 1.3906 \\
\hline 2012 & 1.0158 & 1.6024 & 0.8502 & 0.9214 & 0.8459 & 0.5886 & 1.4897 & 0.9425 & 0.7682 \\
\hline 2013 & 1.0170 & 1.0060 & 1.2094 & 1.1258 & 1.1313 & 1.6071 & 1.2302 & 1.1564 & 1.0069 \\
\hline 2014 & 1.0433 & 1.0152 & 1.0806 & 1.0097 & 0.9798 & 1.2027 & 0.7434 & 1.1733 & 0.7286 \\
\hline
\end{tabular}

Notes: BA - Bratislava region, $T T$ - Trnava region, $T N-$ Trenčín region, $N R-N i t r a$ region, $Z A-$ Žilina region, $B B$ - Banská Bystrica region, $P O$ - Prešov region, $K E$ - Košice region

Table 5 Year-on-year change in gross domestic product. Source: [authors]

\begin{tabular}{|c|c|c|c|c|c|c|c|c|c|}
\hline \multirow{2}{*}{ Year } & \multirow{2}{*}{$\begin{array}{r}\text { Slovak } \\
\text { republic }\end{array}$} & \multicolumn{8}{|c|}{ Regions of Slovak republic } \\
\hline & & BA & TT & $\mathrm{TN}$ & NR & $\mathrm{ZA}$ & $\mathrm{BB}$ & $\mathrm{PO}$ & $\mathrm{KE}$ \\
\hline 2000 & - & - & - & - & - & - & - & - & - \\
\hline 2001 & 1.1364 & 1.1231 & 1.1089 & 1.1319 & 1.1113 & 1.1508 & 1.1547 & 1.1487 & 1.1771 \\
\hline 2002 & 1.1275 & 1.1563 & 1.1029 & 1.0956 & 1.1227 & 1.1155 & 1.1544 & 1.1469 & 1.0983 \\
\hline 2003 & 1.0604 & 1.0578 & 1.1050 & 1.0648 & 1.0848 & 1.0385 & 1.0515 & 1.0407 & 1.0444 \\
\hline 2004 & 1.1226 & 1.1286 & 1.1355 & 1.1266 & 1.1408 & 1.1361 & 1.0754 & 1.1111 & 1.1166 \\
\hline 2005 & 1.1414 & 1.2318 & 1.1701 & 1.0837 & 1.1440 & 1.1603 & 0.9944 & 1.1240 & 1.0953 \\
\hline 2006 & 1.0982 & 1.0574 & 1.2412 & 1.1614 & 1.0575 & 1.0800 & 1.1264 & 1.0214 & 1.0980 \\
\hline 2007 & 1.1456 & 1.1689 & 1.1316 & 1.1281 & 1.1121 & 1.1847 & 1.1465 & 1.1508 & 1.1182 \\
\hline 2008 & 1.0635 & 1.0438 & 1.0192 & 1.0427 & 1.0782 & 1.1028 & 1.0759 & 1.1366 & 1.0627 \\
\hline 2009 & 0.9639 & 1.0294 & 0.9297 & 0.9408 & 0.9609 & 0.9566 & 0.9333 & 0.9497 & 0.9161 \\
\hline 2010 & 1.0555 & 1.0455 & 1.0771 & 1.0501 & 1.0352 & 1.0819 & 1.0632 & 1.0351 & 1.0663 \\
\hline 2011 & 1.0099 & 1.0049 & 0.9949 & 1.0031 & 1.0665 & 0.9754 & 0.9757 & 1.0571 & 1.0158 \\
\hline 2012 & 1.0328 & 1.0184 & 1.0350 & 1.0320 & 1.0360 & 1.0325 & 1.0424 & 1.0515 & 1.0418 \\
\hline 2013 & 1.0416 & 1.0630 & 1.0150 & 1.0322 & 1.0150 & 1.0364 & 1.0611 & 1.0450 & 1.0394 \\
\hline 2014 & 1.0432 & - & - & - & - & - & - & - & - \\
\hline
\end{tabular}

Notes: $B A-$ Bratislava region, $T T-$ Trnava region, $T N-$ Trenčín region, $N R-$ Nitra region, $Z A-$ Žilina region, $B B$ - Banská Bystrica region, $P O$ - Prešov region, $K E$ - Košice region

The following Figure 1 shows the year-on-year changes in road freight transport performance and gross domestic product output in the Slovak Republic and per region. On the basis of data 
availability and for a more transparent view, pairs were selected for the period 2008-2013. The Quadrant graph is divided into 4 quadrants. The I. quadrant represents a year-on-year increase in GDP and an increase in road freight transport performance. Points of ordered pairs in II. quadrant indicate the growth of transport performance in individual regions and a year-on-year decline in growth of GDP. The year-on-year decline in transport performance and the fall in GDP occurred in five regions (quadrant III.). Quadrant IV. shows GDP growth as well as a year-on-year decline in transport performance. The most arranged pairs are located in the I. quadrant. The ideal position of points is in I. and II. quadrant, where the transport performance of road freight transport and GDP are also rising or falling [9-11].

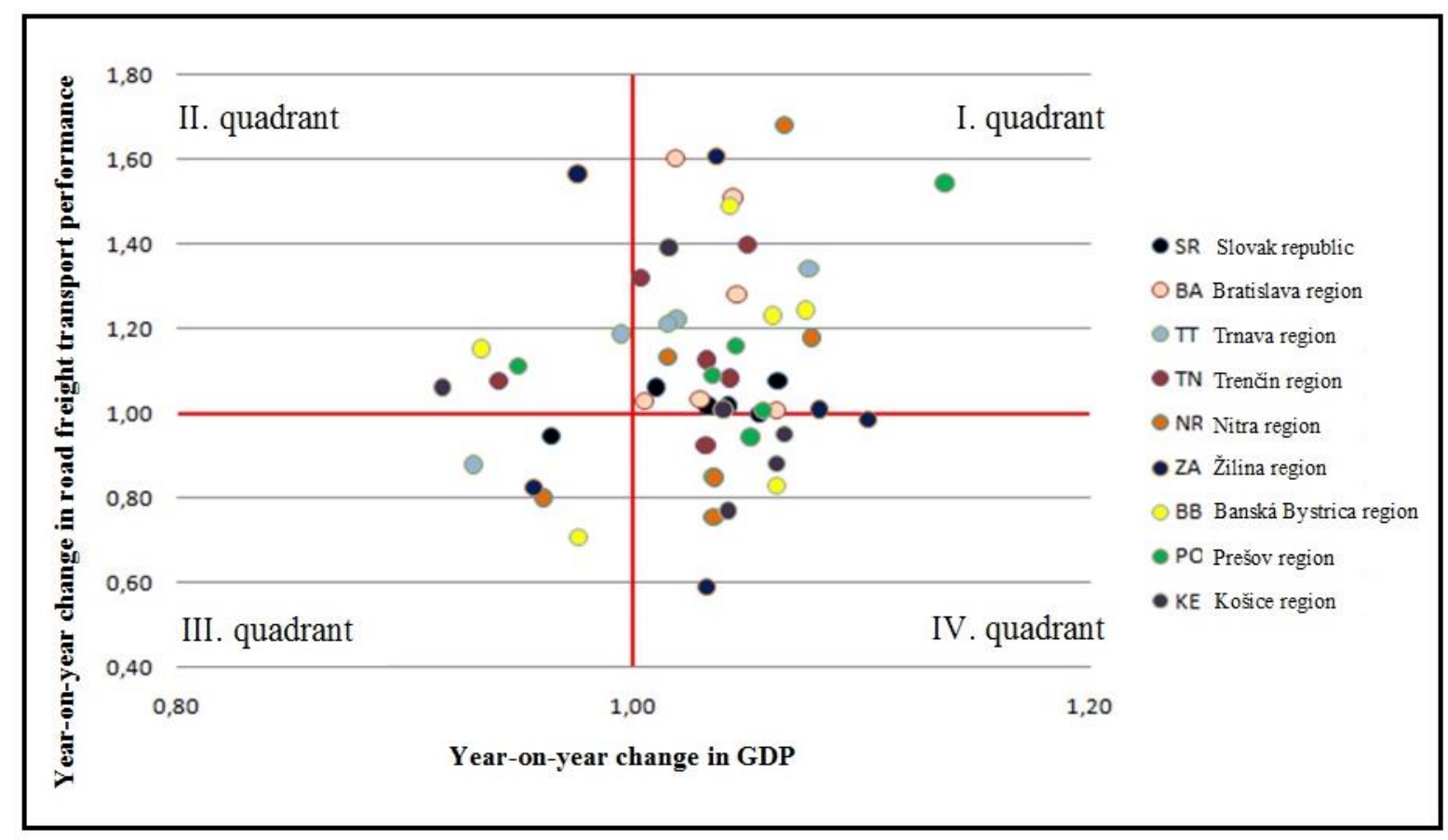

Fig. 1 Relationship between year-on-year change in GDP and freight transport performance.

\section{Source: [authors]}

In Figure 2, the quadrant graph shows arranged pairs of year-on-year changes in employment rates and year-to-year changes in road freight transport performance. Year-on-year change in employment was determined through chain indexes.

The points are scattered in each quadrant approximately in the same number, but the most points are in I. quadrant. The ideal position of the points is in the I. quadrant, where the increase in the road freight transport performance is also increasing the employment rate. II. quadrant shows the year-on-year growth in transport performance and a year-on-year decline in employment rates. The decline in transport performance and employment rates are shown in III. quadrant. Points in IV. quadrant shows organized couples where the employment rate has risen year-on-year regionally, while the transport performance of road freight has decreased [12]. 


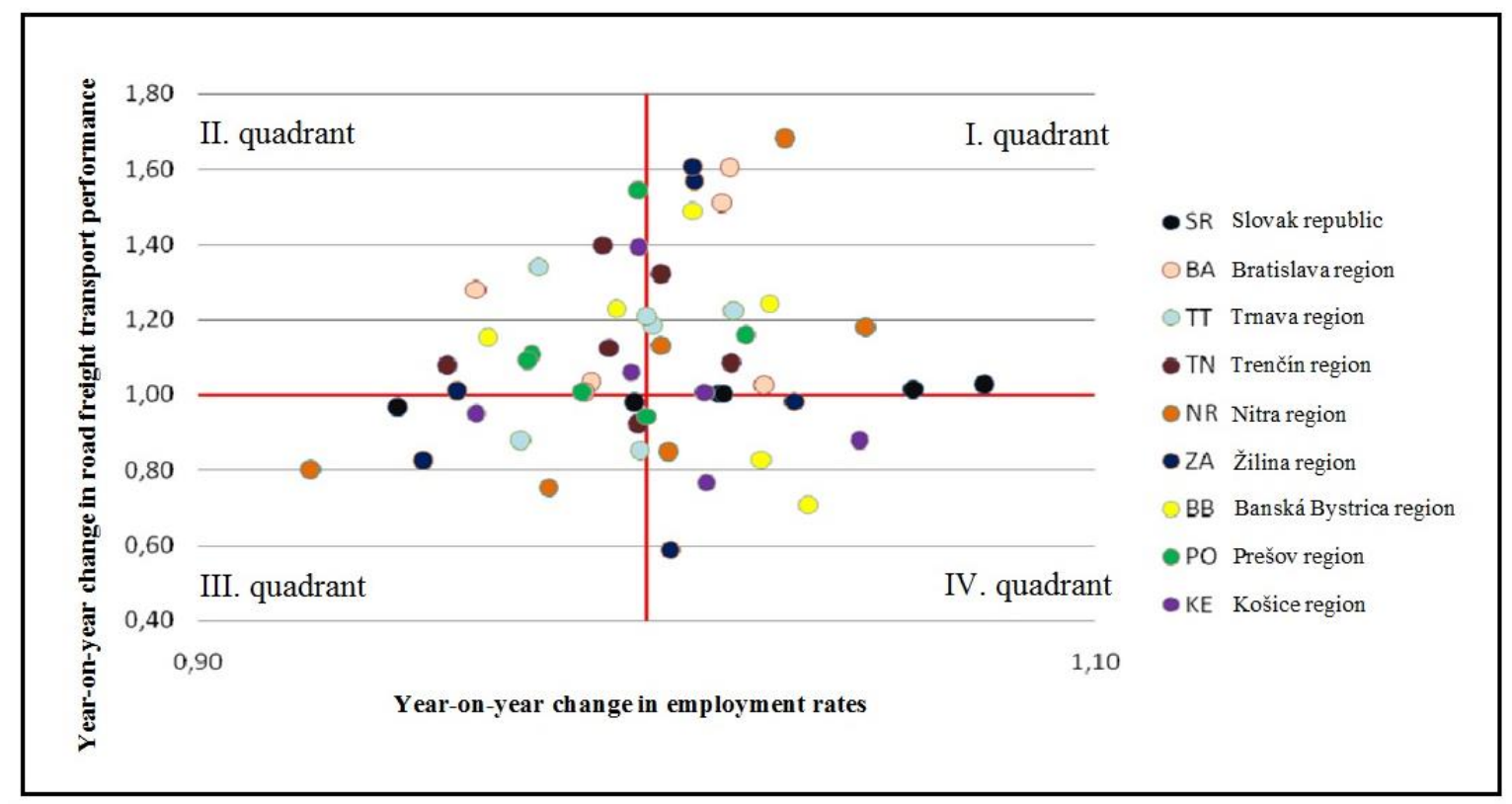

Fig. 2 Comparison of year-on-year change in employment rates and freight transport performance.

Source: [authors]

\section{Conclusion}

The analysis shows that road freight transport is the most used mode of transportation in the Slovak republic. The performance of road transport has increased in the period under review. A positive externality from the construction of a superior infrastructure can be a reduction in accident rate, mortality and thus a reduction in losses on social production in the case of the employment of the undead people. Road infrastructure is considered to be a tool to support the development of the regions of the Slovakia.

However, transport is not the only factor determining the economical and economic growth of the countryside. Demand for transport is a derived demand, in other way it results from the demand of businesses and the population for goods, raw materials and services. However, the aim of the analysis was to point to the positive impact of road transport on the country's economy. Based on the results of the correlation, regression analysis, sensitivity indicator and index-quadrant method, we can assert that the transport performance in road freight transport has undeniable positive influence on selected indicators representing the social and economic growth of the country.

\section{References}

[1] http://www.economicsonline.co.uk/Market_failures/Positive_externalities.html

[2] European Energy and Transport, Trends to 2030.[online]. Available on internet:<https://ec.europa.eu/energy/sites/ener/files/documents/trends_to_2030_update_2009 .pdf $>$.

[3] https://www.enviroportal.sk/uploads/spravy/doprava-sektor-09.pdf 
[4] Masárová, J. (2016) Cestná infraštruktúra v SR. Perners Contacts, 8(3), 113-124, ISSN 1801$674 X$.

[5] www.telecom.gov.sk/pk/070259/dovodova.rtf

[6] http://www3.ekf.tuke.sk/konfera2008/zbornik/files/prispevky/burger.pdf

[7] Statistical Office of Slovak republic. [online]. Available on internet: https://slovak.statistics.sk

[8] Poliak, M. \& Konečný, V. (2007). Ekonomika cestnej a mestskej dopravy 1 - návody na cvičenia. Žilina: EDIS.

[9] Mikušková, M. (2016). Návrh metodiky pre hodnotenie pozitívnych externalít z cestnej dopravy. Diploma thesis. Supervisor of diploma thesis: doc. Ing. Vladimír Konečný, PhD.

[10] Meszaros, F., Markovits-Somogyi, R. \& Bokor, Z. (2012). Modelling and multi-criteria optimization of road traffic flows considering social and economic aspects. Logi, 3(1), 70-82. ISSN 1804-3216.

[11] Mostert, M. \& Limbourg, S. (2016). External Costs as Competitiveness Factors for Freight Transport - A State of the Art. Transport Reviews, 36(6), 692-712. DOI: 10.1080/01441647.2015.1137653.

[12] Yearbooks of Transport, Posts and Telecommunications of the Slovak republic for 2000 2015. 